\title{
Regional variation of relationship between total length and otolith sizes in the three Atherina boyeri Risso, 1810 populations, Turkey
}

\section{Türkiye'deki üç Atherina boyeri Risso, 1810 popülasyonunun total boy ile otolit boyutları arasındaki ilişkilerinin bölgesel varyasyonu}

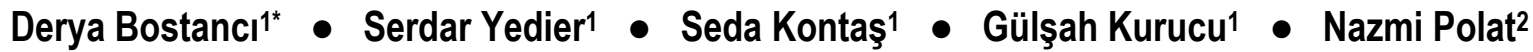

1 Department of Biology, Ordu University, Ordu, Turkey

2 Department of Biology, 19 Mayıs University, Samsun, Turkey

*Corresponding author: deryabostanci@gmail.com

How to cite this paper:

Bostancı, D., Yedier, S., Kontaş, S., Kurucu, G. \& Polat, N. (2017). Regional variation of relationship between total length and otolith sizes in the three Atherina boyeri Risso, 1810 populations, Turkey. Ege Journal of Fisheries and Aquatic Sciences, 34(1): 11-16. doi:10.12714/egejfas.2017.34.1.02

\begin{abstract}
This study focuses on the relationships between otolith measurements and total length; otolith shape indices and the total length; among otolith measurements for three Atherina boyeri populations (Lake Eğirdir, Lake İznik, and Hirfanlı Dam Lake) to determine regional variations of these populations in Turkey. 356 specimens with $41.0-103.6 \mathrm{~mm}$ total length of three $A$. boyeri populations were examined and their otoliths were extracted and measured. Otolith width is the strongest indicator for the three $A$. boyeri populations although the otolith length, width, and weight are good indicators for the fish length in the different populations. The linear relationship was determined between $A$. boyeri total length and sagittal otolith sizes in the three populations. However, the best model for the relationships among otolith sizes can be change depends on populations differentiation. Exponential model is the best model for Lake Eğirdir population while the linear model is the best model for Lake İznik and Hirfanlı Dam Lake populations.
\end{abstract}

Keywords: Atherina boyeri, sagittal otolith, linear relationship, exponential model

Öz: Bu çalışmada Türkiye'deki Atherina boyerinnin üç popülasyonundaki (Eğirdir Gölü, İznik Gölü ve Hirfanlı Baraj Gölü) balıkların total boy-otolit ölçümleri; total boy-otolit indisleri ve otolit ölçümlerinin kendi aralarındaki ilişkileri tespit ederek popülasyonlar arasındaki farklılıkları belirlemeye odaklanılmıştır. Farklı üç bölgeden toplam 356 adet 41.0-103.6 mm total boyunda örnekler yakalanmış ve bu örneklerin sagittal otolitleri çıkarlıp ölçümleri yapılmıştır. Otolit boyu, genişliği ve ağırlığı farklı popülasyonlardaki balıkların boyu için iyi bir gösterge iken otolit genişliği bu üç popülasyon için en kuvvetli göstergedir. Bu üç popülasyondaki $A$. boyeri”nin total boyuyla otolit boyutları arasında doğrusal bir ilişki belirlendi. Ancak bu otolit boyutları arasındaki en iyi ilişki modeli popülasyon farklılıklarına göre değişebilmektedir. Üssel model Eğirdir Gölü popülasyonu için en iyi model iken doğrusal model İznik ve Hirfanlı Gölleri popülasyonları için en iyi model olarak belirlenmiştir.

Anahtar kelimeler: Atherina boyeri, sagittal otolit, doğrusal ilişki, üssel model

\section{INTRODUCTION}

Otoliths, commonly known as "earstones" are calcium carbonate structures located in the teleost fish inner ear. In general, all bony fish have three pairs of otoliths: the sagittae, asteriscus, and lapillus. The otoliths are responsible for the balance, orientation, and auditory reception in fish (Popper and Platt, 1993). The otoliths have long been recognized as species-specific bony structures (Campana, 2004; Tuset et al., 2008; Tombari et al., 2011; Bostanci et al., 2015; Libungan et al., 2015); therefore, fisheries biologists have commonly used sagittal otolith to determine age and growth of fishes in several studies because of their large size and distinct growth rings (Chilton and Beamish, 1982; Boehlert, 1985; Summerfelt and Hall, 1987). There are several biotic and abiotic characters influence the fish growth and otoliths features (Kéver et al.,
2014). For instance, species or populations, which inhabit warm waters, have relatively larger and heavier otoliths than species or populations, which inhabit cold water (Torres et al., 2000). The calcification affects the relationships, otolith morphology, shape, and shape indices; therefore, regional differences and water parameters are important criteria to compare the fish populations.

Big-scale sand smelt, Atherina boyeri is a small amphidromous euryhaline teleost fish (Bartulović et al., 2006; Kottelat and Freyhof, 2007) abundantly inhabiting the Mediterranean, Northeast Atlantic and Turkish inland waters. In Turkey, A. boyeri were commercially important (Saç et al., 2015) and they were considered invasive species in Turkish 
waters (Tarkan et al., 2015). A. boyeri has been found as prey of the largemouth bass, Micropterus salmoides and the northern pike, Esox lucius (Lorenzoni et al., 2002), the twaite shad, Alosa fallax (Ceyhan et al., 2012), the pike - perch, Sander lucioperca (Yağcı et al., 2014), and the european perch, Perca fluviatilis (Saç et al., 2015) in marine and freshwaters. In general, prey fish otoliths are undigested and they remain in predators' stomachs and intestines. Otolith size - fish length relationships provide important information to determine fish length from otoliths in stomach of predators. The relationship between the total length and otolith dimensions is of great importance (Jawad and Al-Mamry, 2012; Zan et al., 2015) in prey-predator relationships, population management studies, and archaeological research (Harvey et al., 2000; Tuset et al. 2008). Total length-otolith size relationships and their significance may vary among fish species or among different populations of the same species (Hunt, 1992). The relationship between fish length and otolith size has been used successfully in several studies for invasive and native marine and freshwater fish species (Battaglia et al., 2015; Humston et al., 2015; Zan et al., 2015; Viva et al., 2015; Yılmaz et al., 2015).

Despite the increase in the relationship between fish size and otolith size studies throughout the world, fish size-otolith size and total length-otolith measurements relationships are limited and even unknown for invasive species in Turkish waters. The present study provides detailed information on predictive relationships; (i) between sagittal otolith measurements-total length in the three $A$. boyeri populations (Lake Eğirdir, Lake İznik and Hirfanlı Dam Lake) with linear and exponential models, and (ii) among $A$. boyeri otolith morphometric parameters in each population.

\section{MATERIALS AND METHODS}

The fish samples were collected from commercial anglers in Lake İznik (Bursa), Lake Eğirdir (Isparta), and Hirfanlı Dam Lake (Kırşehir), Turkey (Figure 1).

Total length $(T L)$ was measured to the nearest $1 \pm 0.01 \mathrm{~mm}$ for each $A$. boyeri. Their weight (W) was recorded to the $0.1 \pm 0.01 \mathrm{~g}$, and the sagittal pairs were removed, cleaned, dried and then weighted (OWE) to the nearest $0.0001 \mathrm{~g}$. Left and right otolith morphometric parameters such as otolith length, width, perimeter, and area were measured using Leica S8APO brand microscope with computer-connected camera system. Using the otolith morphometric parameters, the shape indices
[Form Factor (FF), Roundness (RD), Aspect Ratio (AR), Circularity (C), Rectangularity (R), Ellipticity (E)] were calculated to describe the otolith shape (Ponton, 2006; Tuset et al., 2003).

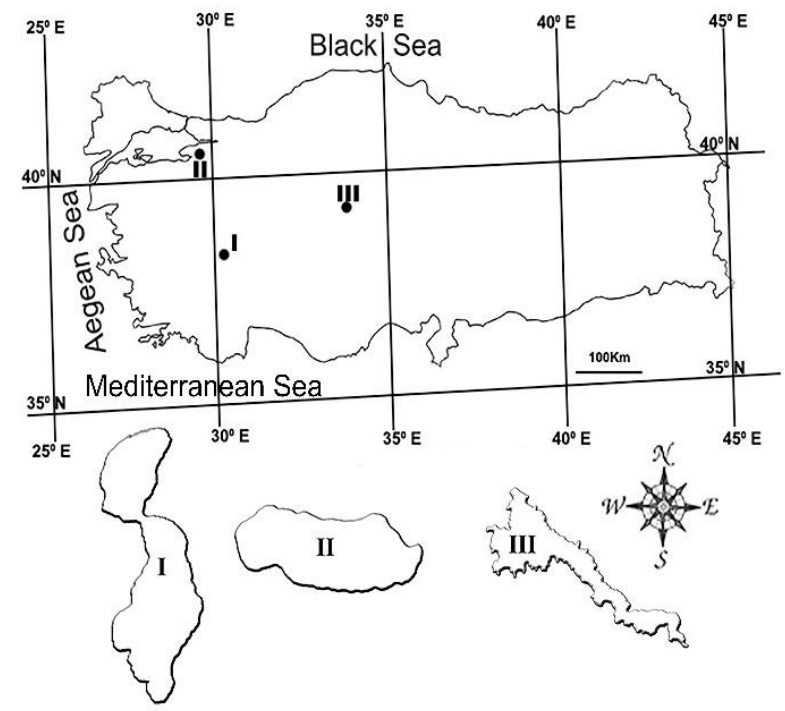

Figure 1. Three sampling areas for Atherina boyeri in Turkey; I: Lake Eğirdir (Isparta), II: Lake İnik (Bursa), III: Hirfanlı Dam Lake (Kırşehir)

In the present study, a MINITAB 17.0 statistical analysis program was used for all calculations. All data were tested using the Kolmogorov-Smirnov test for normality and homogeneity of variance were tested using the Levene test. In addition, right and left sagittal otoliths were investigated with a paired $t$ - test using the same statistical analysis program for all the fish samples. Moreover, linear and exponential relationships were determined which equations best fit (i) between the otolith morphometric parameters and TL, (ii) between the otolith shape indices and TL, (iii) among otolith morphometric parameters in the three $A$. boyeri populations.

\section{RESULTS}

A total of 356 specimens in the three $A$. boyeri populations were collected and their total lengths and weights ranged from $58.98-95.00 \mathrm{~mm}$ and 1.35 - $5.39 \mathrm{~g}$ for Lake Eğirdir population ( $\mathrm{n}=174), 63.67-103.63 \mathrm{~mm}$ and $1.53-6.05 \mathrm{~g}$ for Lake İznik population ( $n=58)$, and $41.00-99.00 \mathrm{~mm}$ and $0.80-5.40 \mathrm{~g}$ for Hirfanlı Dam Lake population ( $n=124)$ (Table 1).

Table 1. Minimum-maximum total length (TL) and weight (W) of Atherina boyeri and descriptive statistics values of left otolith morphometric parameters in Lake Eğirdir, Lake İnik, and Hirfanlı Dam Lake

\begin{tabular}{|c|c|c|c|c|c|c|c|}
\hline \multicolumn{8}{|c|}{ Otolith Morphometric Parameters } \\
\hline $\begin{array}{l}\text { Species } \\
\text { Regions }\end{array}$ & $\begin{array}{c}\text { Fish } \\
\text { Weight }(g)\end{array}$ & $\begin{array}{c}\text { Fish } \\
\text { TL }(\mathrm{mm})\end{array}$ & $\begin{array}{l}\text { Otolith Length } \\
(\mathrm{mm})\end{array}$ & $\begin{array}{l}\text { Otolith Width } \\
\text { (mm) }\end{array}$ & $\begin{array}{c}\text { Otolith } \\
\text { Weight (g) }\end{array}$ & $\begin{array}{l}\text { Otolith Perimeter } \\
\text { (mm) }\end{array}$ & $\begin{array}{c}\text { Otolith } \\
\text { Area }\left(\mathrm{mm}^{2}\right)\end{array}$ \\
\hline $\begin{array}{l}\text { Lake Eğirdir } \\
\quad(n=174)\end{array}$ & $1.3-5.3$ & $58.9-95.0$ & $\begin{array}{l}2.113-3.657 \\
2.752 \pm 0.015\end{array}$ & $\begin{array}{l}0.989-2.104 \\
1.790 \pm 0.009\end{array}$ & $\begin{array}{c}0.0011-0.0043 \\
0.0027 \pm 0.00004\end{array}$ & $\begin{array}{r}5.656-8.560 \\
7.397 \pm 0.037\end{array}$ & $\begin{array}{l}2.089-4.806 \\
3.574 \pm 0.034\end{array}$ \\
\hline $\begin{array}{l}\text { Lake İznik } \\
\qquad(n=58)\end{array}$ & $1.5-6.0$ & $63.6-103.6$ & $\begin{array}{c}1.935-3.192 \\
2.411 \pm 0.046\end{array}$ & $\begin{array}{l}1.329-2.167 \\
1.629 \pm 0.028\end{array}$ & $\begin{array}{c}0.0010-0.0044 \\
0.0017 \pm 0.00013\end{array}$ & $\begin{array}{l}5.665-9.050 \\
6.881 \pm 0.115\end{array}$ & $\begin{array}{l}1.9165-5.054 \\
2.879 \pm 0.112\end{array}$ \\
\hline $\begin{array}{l}\text { Hirfanlı Dam Lake } \\
\qquad(n=124)\end{array}$ & $0.8-5.4$ & $41.0-99.0$ & $\begin{array}{l}1.512-3.410 \\
2.154 \pm 0.032\end{array}$ & $\begin{array}{l}1.027-2.311 \\
1.428 \pm 0.020\end{array}$ & $\begin{array}{c}0.0003-0.0052 \\
0.0013 \pm 0.00007\end{array}$ & $\begin{array}{l}4.032-9.206 \\
5.697 \pm 0.086\end{array}$ & $\begin{array}{l}1.117-5.481 \\
2.264 \pm 0.072\end{array}$ \\
\hline
\end{tabular}


According to statistical analysis results, homogeneity of variances was not significant (Levene's test, $P>0.05$ ) and a normal distribution was detected (Kolmogorov - Smirnov test, $P$ $>0.05$ ). Interpretation of paired $t$ test results, the differences between right and left sagittal otoliths were not significant $(P>$ 0.05). The left otoliths were preferred for further calculations. Besides, the big-scale sand smelt otoliths were shown from the three $A$. boyeri populations in the different inland waters (Figure 2).

Descriptive statistics were performed on each of the datasets for three $A$. boyeri populations and the results were presented in Table 1 and Table 2 for otolith morphometric parameters and shape indices, respectively. Regression equation and coefficients of determination $\left(R^{2}\right)$ for linear (LR) and exponential (ER) the relationships; among otolith morphometric parameters, between $A$. boyeri total length and the otolith parameters in the three regions; Lake Eğirdir, Lake İnik and Hirfanlı Dam Lake were shown in Table 3 and relationships such as $\mathrm{OL}$ vs. OW, OL vs. OWE, and OW vs. OWE were also presented (Table 3 ). The relationships are significantly different in the three $A$. boyeri populations $(P<$ 0.001)

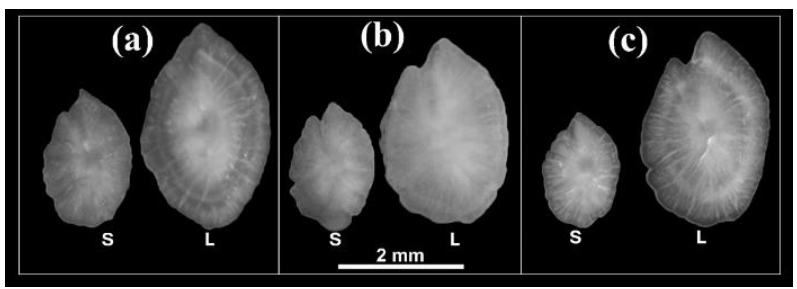

Figure 2. The smallest $(S)$ and the largest $(\mathrm{L})$ left sagittal otoliths for Atherina boyeri populations from (a) Lake Eğirdir, (b) Lake İznik, and (c) Hirfanlı Dam Lake in Turkey

Table 2. Descriptive statistics values of left otolith shape indices of Atherina boyeri in Lake Eğirdir, Lake İznik, and Hirfanlı Dam Lake

\begin{tabular}{|c|c|c|c|c|c|c|}
\hline \multicolumn{7}{|c|}{ Otolith Shape Indices } \\
\hline Species Regions & Form Factor & Roundness & Aspect Ratio & Circularity & Rectangularity & Ellipticity \\
\hline Lake Eğirdir & $0.544-0.869$ & $0.315-0.692$ & $1.351-3.047$ & $14.441-23.075$ & $0.487-1.463$ & $0.149-0.505$ \\
\hline$(n=174)$ & $0.817 \pm 0.002$ & $0.600 \pm 0.002$ & $1.543 \pm 0.011$ & $15.388 \pm 0.050$ & $0.725 \pm 0.005$ & $0.211 \pm 0.008$ \\
\hline Lake İznik & $0.620-0.823$ & $0.556-0.700$ & $1.344-1.661$ & $15.251-20.257$ & $0.670-0.769$ & $0.147-0.248$ \\
\hline$(n=58)$ & $0.749 \pm 0.006$ & $0.621 \pm 0.003$ & $1.478 \pm 0.008$ & $16.833 \pm 0.150$ & $0.720 \pm 0.002$ & $0.192 \pm 0.002$ \\
\hline Hirfanlı Dam Lake & $0.767-0.966$ & $0.528-0.694$ & $1.372-1.723$ & $12.998-16.365$ & $0.684-0.765$ & $0.157-0.265$ \\
\hline$(n=124)$ & $0.857 \pm 0.002$ & $0.608 \pm 0.002$ & $1.508 \pm 0.005$ & $14.671 \pm 0.046$ & $0.719 \pm 0.001$ & $0.202 \pm 0.001$ \\
\hline
\end{tabular}

$\mathrm{n}=$ Sample size

Table 3. Regression equation and coefficients of determination $\left(R^{2}\right)$ for linear $(L R)$ and exponential (ER) relationships among left otolith morphometric parameters, between the left otolith parameters and total length (TL) of Atherina boyeri in Lake Eğirdir, Lake İznik, and Hirfanlı Dam Lake

\begin{tabular}{|c|c|c|c|c|c|c|c|}
\hline \multirow{2}{*}{$\begin{array}{l}\text { Species } \\
\text { Regions }\end{array}$} & \multirow{2}{*}{ Relationship } & \multicolumn{2}{|c|}{ Regression Equation } & \multicolumn{2}{|c|}{$\mathbf{R}^{2}$} & \multicolumn{2}{|c|}{ Significance } \\
\hline & & Linear & Exponential & LR & ER & LR & ER \\
\hline \multirow{6}{*}{ 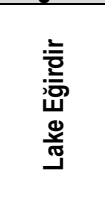 } & TL vs. OL & $y=0.0284 x+0.4793$ & $y=1.1915 e^{0.0104 x}$ & 0.6585 & 0.6529 & $P<0.001$ & $P<0.001$ \\
\hline & TL vs. OW & $y=0.0150 x+0.6035$ & $y=0.9303 e^{0.0082 x}$ & 0.6726 & 0.6677 & $P<0.001$ & $P<0.001$ \\
\hline & TL vs. OWE & $y=0.00008 x-0.0035$ & $y=0.0002 e^{0.0302 x}$ & 0.6267 & 0.6152 & $P<0.001$ & $P<0.001$ \\
\hline & OL vs. OW & $y=0.4602 x+0.5365$ & $y=0.8830 e^{0.2588 x}$ & 0.6850 & 0.6874 & $P<0.001$ & $P<0.001$ \\
\hline & OL vs. OWE & $y=0.0025 x-0.0040$ & $y=0.0002 e^{0.9569 x}$ & 0.7530 & 0.7564 & $P<0.001$ & $P<0.001$ \\
\hline & OW vs. OWE & $y=0.0044 x-0.0052$ & $y=0.0001 e^{1.7058 x}$ & 0.7338 & 0.7387 & $P<0.001$ & $P<0.001$ \\
\hline \multirow{6}{*}{$\frac{\text { 兰 }}{\frac{\text { N }}{\mathscr{\Xi}}}$} & TL vs. OL & $y=0.0332 x-0.1159$ & $y=0.8944 e^{0.0129 x}$ & 0.8807 & 0.8577 & $P<0.001$ & $P<0.001$ \\
\hline & TL vs. OW & $y=0.0205 x+0.0744$ & $y=0.6618 e^{0.0118 x}$ & 0.8833 & 0.8672 & $P<0.001$ & $P<0.001$ \\
\hline & TL vs. OWE & $y=0.0001 x-0.0055$ & $y=0.00006 e^{0.0434 x}$ & 0.8712 & 0.8257 & $P<0.001$ & $P<0.001$ \\
\hline & OL vs. OW & $y=0.5861 x+0.2164$ & $y=0.7135 e^{0.3393 x}$ & 0.9124 & 0.9110 & $P<0.001$ & $P<0.001$ \\
\hline & OL vs. OWE & $y=0.0028 x-0.0049$ & $y=0.00007 e^{1.2828 x}$ & 0.9136 & 0.9095 & $P<0.001$ & $P<0.001$ \\
\hline & OW vs. OWE & $y=0.0044 x-0.0054$ & $y=0.00006 e^{2.028 x}$ & 0.8748 & 0.8610 & $P<0.001$ & $P<0.001$ \\
\hline \multirow{6}{*}{ 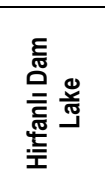 } & TL vs. OL & $y=0.0336 x+0.1426$ & $y=0.8922 e^{0.0145 x}$ & 0.9130 & 0.8950 & $P<0.001$ & $P<0.001$ \\
\hline & TL vs. OW & $y=0.0216 x+0.1368$ & $y=0.6069 e^{0.0141 x}$ & 0.9232 & 0.9075 & $P<0.001$ & $P<0.001$ \\
\hline & TL vs. OWE & $y=0.0008 x-0.0031$ & $y=0.00008 e^{0.0453 x}$ & 0.8420 & 0.8346 & $P<0.001$ & $P<0.001$ \\
\hline & OL vs. OW & $y=0.6170 x+0.0991$ & $y=0.5925 e^{0.4034 x}$ & 0.9339 & 0.9165 & $P<0.001$ & $P<0.001$ \\
\hline & OL vs. OWE & $y=0.0022 x-0.0033$ & $y=0.00008 e^{1.2502 x}$ & 0.8584 & 0.8472 & $P<0.001$ & $P<0.001$ \\
\hline & OW vs. OWE & $y=0.0034 x-0.0034$ & $y=0.00008 e^{1.932 x}$ & 0.8367 & 0.8249 & $P<0.001$ & $P<0.001$ \\
\hline
\end{tabular}

$\mathrm{R}^{2}=$ Coefficient of determination

In current study, the relationships among otolith size (length, width, weight) successfully calculated for each $A$. boyeri population in the three Turkish inland waters. The relationship was detected from as an exponential model which is much more useful with the highest correlations $R^{2}=0.6874$ for OL vs. OW, $R^{2}=0.7564$ for OL vs. OWE and $R^{2}=0.7387$ OW vs. OWE ( $P<0.001)$ in Lake Eğirdir population (Table 3$)$. Linear model was determinate the best model in the relationship between TL and otolith size for the Lake İnik and Hirfanlı Dam Lake populations (Table 3). Present study shows 
a strong relationship between the otolith width and total length obtained $\left(R^{2}=0.6726\right)$ and moderate relationship between total length and otolith length; otolith weight $\left(R^{2}=0.6585 ; R^{2}=\right.$ 0.6267 , respectively) for the Lake Eğirdir population. Similarly, strong relationships between total length and otolith length; otolith width; otolith weight $\left(R^{2}=0.8807 ; R^{2}=0.8833 ; R^{2}=\right.$ 0.8712, respectively) were detected in the Lake Iznik population. Besides, the highest correlations between fish length and otolith length; otolith width; otolith weight in the Hirfanlı Dam Lake population were found within the three populations $\left(R^{2}=0.9130 ; R^{2}=0.9232 ; R^{2}=0.8426\right.$, respectively). In addition, the relationship between otolith shape indices and total length was presented as graphically for the three populations (Fig. 3).

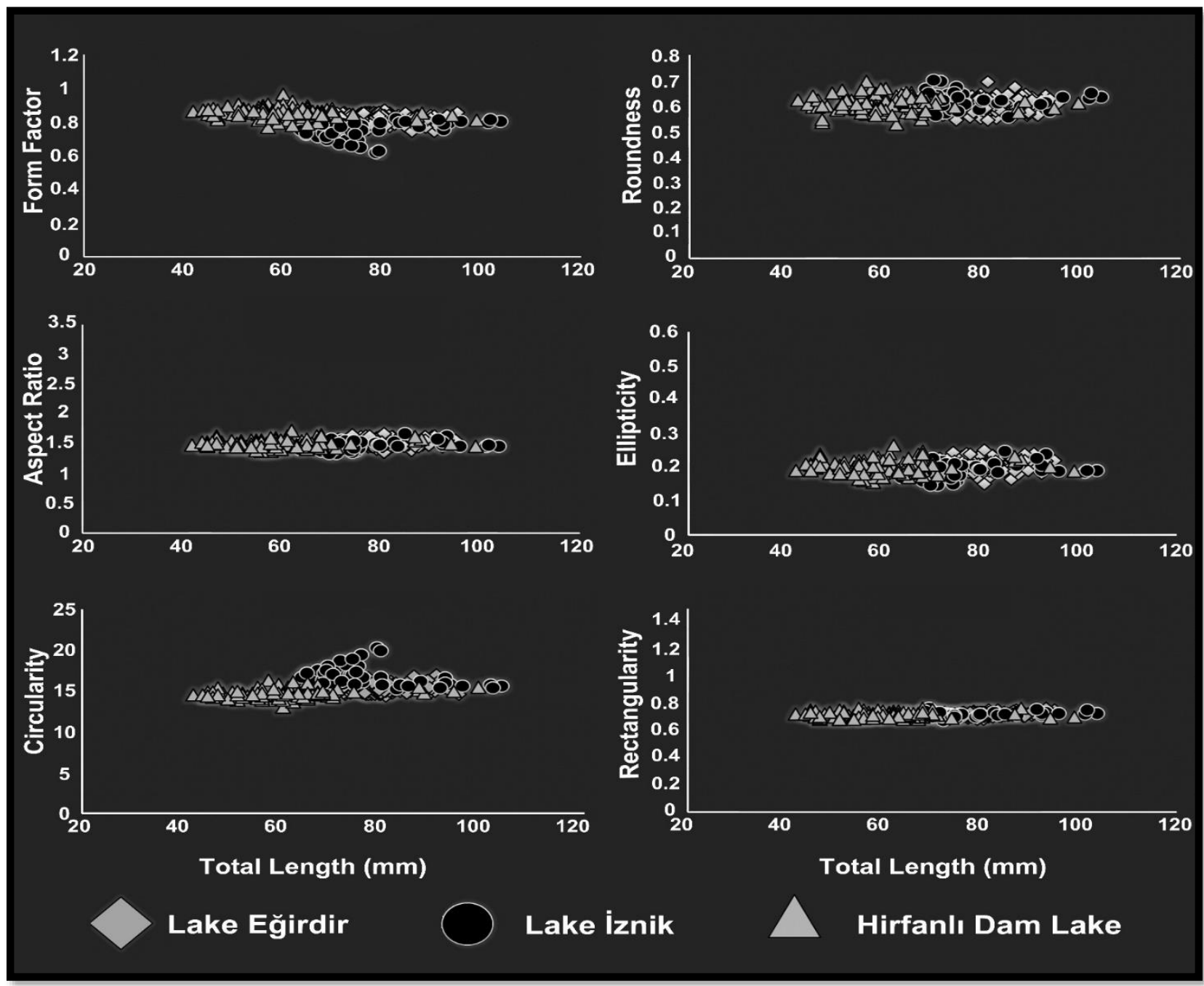

Figure 3. The relationships between total length and left sagittal otolith shape indices of caught Atherina boyeri from Lake Eğirdir, Lake İnik, Hirfanlı Dam Lake in Turkey

\section{DISCUSSION}

The current study provides a useful tool for better understanding the environmental and the habitat effect on the relationships for the three $A$. boyeri populations in the different inland waters. This is the first information on otolith dimensionstotal length relationship of $A$. boyeri inhabiting three different Turkish lakes (Lake Eğirdir, Lake İznik, and Hirfanlı Dam Lake). In this study, linear relationships existed between otolith size and the fish lengths for the three different populations. However, relationships among otolith size (weight, length, and width) were varied for instance, linear for Lake İnik and Hirfanlı Dam Lake populations, and exponential for Lake Eğirdir. This variation can be highly likely due to the possible differences in environmental conditions, ontogenetic spatial shift, food abundance, migration, and spatial niches as adaptation, which is an important step to spread for invasive fish. Invasive fish species, deliberately introduced from different freshwater and marine habitats, provide an important tool that may prove beneficial in evaluating the relative influence of environmental and genetic conditions on otolith variables (Vignon and Morat, 2010). 
Previous studies were generally focused on the relationship between fish length and one or two otolith measurements (Granadeiro and Silva, 2000; Harvey et al., 2000; Waessle et al., 2003; Battaglia et al., 2010). There is no information about the otolith shape indices - total length relationship for $A$. boyeri; therefore, the present study is a pioneer study in this perspective. Generally, fish length is linearly related to otolith length. Contrary to expectations, the relationship is not always applicable to species. For instance, Jawad et al., (2011) noted that Rastrelliger kanagurta size strongly related to their otolith weight. In the current study, otolith width, length, and weight are noted a good indicator for $A$. boyeri total length in Hirfanlı Dam Lake population; these results are consistent with Waessle et al., (2003) and Jawad et al., (2011). For the Lake İznik population, otolith width is the strongest indicator, but otolith length and otolith weight also are a good indicator for the same population.

Pombo et al., (2005) indicated that fish length - otolith length relationships of Atherina boyeri and $A$. presbyter which are two sympatric species, were not statistically different $(P>$ 0.05) in different locations of the Ria de Aveiro, Portugal. However, the present study result about the relationship between fish length and otolith length $A$. boyeri was statistically different $(P<0.001)$ in the three habitats. Martucci et al., (1993) reported that undigested $A$. boyeri otoliths in Phalacrocorax carbo pellets can be used to determine consumed fish size and weight. As reported in Martucci et al., (1993), the mean length, width, and weight of undigested sand smelt otoliths were 2.65 $\mathrm{mm}, 2.45 \mathrm{~mm}$ and $0.005 \mathrm{~g}$, respectively. These values vary in the present study (Table 1). For instance, otolith weight and otolith width bigger in the present study. According to the study, they regressed whole otolith length against total body length for A. boyeri. They also calculated a strong relationship between total length and otolith length $\left(R^{2}=0.933\right)$. However, the regression coefficients of the relationship in $A$. boyeri are varied in different habitats $\left(R^{2}=0.658\right.$ in Lake Eğirdir, $R^{2}=0.880$ in Lake İznik, and for $\mathrm{R}^{2}=0.913$ in Hirfanlı Dam Lake).

Fernandez-Jover and Sanchez- Jerez (2015) conducted a study on diet and otolith growth of three fish species, one of

\section{REFERENCES}

Bartulović, V., Glamuzina, B., Conides, A., Gavrilović, A. \& Dulćić, J. (2006) Maturation, reproduction and recruitment of the big-scale sand smelt, Atherina boyeri Risso, 1810 (Pisces: Atherinidae) in the estuary of Mala Neretva River (southeastern Adriatic, Croatia). Acta Adriatica, 47(1): 5-11.

Battaglia, P., Malara, D., Romeo, T. \& Andaloro, F. (2010). Relationship between otolith size and fish size in some mesopelagic and bathypelagic species from the Mediterranean Sea (Strait of Messina, Italy). Scientia Marina, 74(3): 605-612. doi: 10.3989/scimar.2010.74n3605

Battaglia, P., Malara, D., Ammendolia, G., Romeo, T. \& Andaloro, F. (2015). Relationships between otolith size and fish length in some mesopelagic teleosts (Myctophidae, Paralepididae, Phosichthyidae, and Stomiidae). Journal of Fish Biology, 87(3): 774-782. doi: 10.1111/jfb.12744

Bautista-Vega, A.A., Letourneur, Y., Harmelin-Vivien, M. \& Salen-Picar, C. (2008). Difference in diet and size-related trophic level in two sympatric fish species, the red mullets Mullus barbatus and Mullus surmuletus in the them is $A$. boyeri, in two different fish farm companies and three control locations along the southeast coast of Spain in the Mediterranean Sea. They reported that $A$. boyeri otolith-shape descriptors such as otolith area, perimeter, circularity, roundness, aspect ratio were varied in fish farms and natural habitats. Differences in otolith morphometric and biometric variables among fish populations can occur for a number of reasons such as habitat complexity and environmental conditions as well as demographics such as sex, age, population, can influence otolith morphology (Nielsen et al., 2010; Bostanci et al., 2015).

In conclusion, many invasive fish species damage marine and freshwater ecosystems by outcompeting native fish species and therefore determining the size of the invasive species is an important factor in fisheries studies. A. boyeri was an important prey of several predator species among the piscivore fish such as Alosa fallax, Perca fluviatilis, and Sander lucioperca in Turkish waters. The use of the otoliths in prey predator studies is important for the identification and size estimation of the prey fish. The positive and strong correlation between otolith size (width, length, and weight) and total length for the three $A$. boyeri populations were indicated by the current study. Furthermore, otolith width is the most reliable indicator for $A$. boyeri total length in the three populations. However, many fish species in freshwater or marine system are sensible environmental conditions, and/or variations sensitive, during their life history and/or from different regions, habitat and depth (Merigot et al., 2007; Bautista-Vega et al., 2008); therefore, they cause the variations in otolith and fish size (Campana and Casselman, 1993; Reichenbacher et al., 2009). In addition, the current study indicated that individuals of the same species inhabiting different regions have a different growth rate.

The present investigation invasive $A$. boyeri population from the three different regions would certainly add to the knowledge of the relationships (among otolith size; total lengthotolith size relationship; total length - otolith shape indices) and encourage further research on the subject involving many other freshwater and marine species from different regions in the world.

Gulf of Lions (north-west Mediterranean Sea). Journal of Fish Biology, 73(10): 2402-2420. doi: 10.1111/j.1095-8649.2008.02093.x

Boehlert, G.W. (1985). Using objective criteria and multiple regression models for age determination in fishes. Fishery Bulletin, 83(2):103-117.

Bostanci, D., Polat, N., Kurucu, G., Yedier, S., Kontas, S. \& Darcin, M. (2015). Using otolith shape and morphometry to identify four Alburnus species ( $A$. chalcoides, $A$. escherichii, $A$. mossulensis and $A$. tarichi) in Turkish inland waters. Journal of Applied Ichthyology, 31(6): 1013-1022. doi: 10.1111/jai.12860

Campana, S.E. \& Casselman, J.M. (1993). Stock discrimination using otolith shape analysis. Canadian Journal of Fisheries and Aquatic Sciences, 50(5): 1062-1083. doi: 10.1139/f93-123

Campana, S.E. (2004). Photographic Atlas of Fish Otoliths of the Northwest Atlantic Ocean. Ottawa, Ontario: NRC Research Press. 
Ceyhan, T., Akyol, O., Sever, T.M. \& Kara, A. (2012). Diet composition of adult twaite shad (Alosa fallax) in the Aegean Sea (Izmir Bay, Turkey). Journal of the Marine Biological Association of the United Kingdom, 92(3): 601. 604. doi: $10.1017 /$ S0025315411000750

Chilton, D.E. \& Beamish, R.J. (1982). Age determination methods for fishes studied by the groundfish program at the Pacific Biological Station. Canadian Special Publication of Fisheries and Aquatic Sciences, 60, 102 pp.

Fernandez-Jover, D. \& Sanchez-Jerez, P. (2015). Comparison of diet and otolith growth of juvenile wild fish communities at fish farms and natura habitats. ICES Journal of Marine Science, 72(3), 916-929. doi:10.1093/icesjms/fsu153

Granadeiro, J.P. \& Silva, M.A. (2000). The use of otoliths and vertebrae in the identification and size-estimation of fish in predator prey studies. Cybium 24(4): 383-393.

Harvey, J.T., Loughlin, T.R., Perez, M.A. \& Oxman, D.S. (2000). Relationship between fish size and otolith length for 63 species of fishes from the eastern North Pacific Ocean. NOAA Technical Report NMFS, 150,35 pp.

Hunt, J.J. (1992). Morphological characteristics of otoliths for selected fish in the northwest Atlantic. Journal of Northwest Atlantic Fisheries Science, 13:63-75.

Humston, R., Moore, M., Wass, C., Dennis, D. \& Doss, S. (2015). Correlations between body length and otolith size in smallmouth bass Micropterus dolomieu Lacépède, 1802 with implications for retrospective growth analyses. Journal of Applied Ichthyology, 31(5): 883-887. doi: 10.1111/jai.12801

Jawad, L.A., Ambuali, A., Al-Mamyr, J.M. \& Al-Busaidi, H.K. (2011) Relationships between fish length and otolith length, width and weight of the Indian mackerel Rastrelliger kanagurta (Cuvier, 1817) collected from the Sea of Oman. Ribarstvo, 69(2): 51-61.

Jawad, L.A. \& Al-Mamry, J.M. (2012). Relationship between fish length and otolith dimensions in the carangid fish (Carangoides coeruleopinnatus (Ruppell, 1830)) collected from the Sea of Oman. Journal of FisheriesSciences.com, 6(3): 203-208. doi: 10.3153/fscom.2012023

Kéver, L., Colleye, O., Herrel, A., Romans, P. \& Parmentier, E. (2014). Hearing capacities and otolith size in two ophidiform species (Ophidion rochei and Carapus acus). Journal of Experimental Biology, 217: 2517-2525. doi: 10.1242/jeb.105254

Kottelat, M. \& Freyhof, J. (2007). Handbook of European freshwater fishes. Berlin: Publications Kottelat, Cornol and Freyhof.

Libungan, L.A., Óskarsson, G.J., Slotte, A., Arge, J.A. \& Pálsson, S. (2015). Otolith shape: A population marker for Atlantic herring Clupea harengus. Journal of Fish Biology, 86(4): 1377-1395. doi: 10.1111/jfb.12647

Lorenzoni, M., Corboli, M., Dörr, A.J.M., Giovinazzo, G., Selvi, S. \& Mearelli, M. (2002). Diets of Micropterus salmoides Lac. and Esox lucius L. in Lake Trasimeno (Umbria, Italy) and their diet overlap. Bulletin français de la pêche et de la pisciculture, 365/366: 537-547. doi: $10.1051 / \mathrm{kmae}: 2002050$

Martucci, O., Pietrelli, L. \& Consiglio, C. (1993). Fish otoliths as indicators of the cormorant Phalacrocorax carbo diet (Aves, Pelecaniformes). Bolletino di Zoologia, 60(4): 393-396. doi: 10.1080/1125000930935584

Merigot, B., Letourneur, Y. \& Lecomte-Finiger, R. (2007). Characterization of local populations of the common sole Solea solea (Pisces Soleidae) in the NW Mediterranean through otolith morphometrics and shape analysis. Marine Biology, 151(3): 997-1008. doi: 10.1007/s00227-006-0549-0

Nielsen, J.R., Methven, D.A. \& Kristensen, K. (2010). A statistical discrimination method using sagittal otolith dimensions between sibling species of juvenile cod Gadus morhua and Gadus ogac from the northwest Atlantic. Journal of Northwest Atlantic Fishery Science, 43: 27-45. doi:10.2960/J.v43 m667
Pombo, L., Elliott, M. \& Rebelo, J.E. (2005). Ecology, age and growth of Atherina boyeri and Atherina presbyter in the Ria de Aveiro, Portugal. Cybium, 29(1): 47-55.

Ponton, D. (2006). Is geometric morphometrics efficient for comparing otolith shape of different fish species? Journal of Morphology, 267(6): 750-757. doi: $10.1002 /$ jmor.10439

Popper, A. \& Platt, C. (1993). Inner ear and lateral line. In D. Evans (Ed.), The physiology of fishes (pp 99-136). Boca Raton, FL: CRC Press.

Reichenbacher, B., Kamrani, E., Esmaeili, H.R. \& Teimori, A. (2009). The endangered cyprinodont Aphanius ginaonis (Holly, 1929) from southern Iran is a valid species: evidence from otolith morphology. Environmental Biology of Fishes, 86(4): 507-521. doi: 10.1007/s10641-009-9549-5

Saç, G., Gaygusuz, Ö. \& Tarkan, A.S. (2015). Reoccurrence of a Commercial Euryhaline Fish Species, Atherina boyeri Risso, 1810 (Atherinidae) In Büyükçekmece Reservoir (Istanbul, Turkey). Journal of Aquaculture Engineering and Fisheries Research, 1(4): 203-208. doi: $10.3153 / J A E F R 15020$

Summerfelt, R.C. \& Hall, G.E. (1987). The age and growth of fish. Ames: lowa State Univ. Press.

Tarkan, A.S., Marr, S.M. \& Ekmekçi, F.G. (2015). Non-native and translocated freshwater fish species in Turkey. FISHMED Fishes in Mediterranean Environments, 3: 1-28.

Tombari, A.D., Véliz, D. \& Volpedo, A.V. (2011). Spatio-temporal and intraspecific variations on the morphology and morphometry of otoliths on Odontesthes bonariensis (Atheriniformes, Atherinopsidae). Natura Neotropicalis, 42: 45-64.

Torres, G.J., Lombarte, A. \& Morales-Nin, B. (2000). Variability of the sulcus acusticus in the sagittal otolith of the genus Merluccius (Merluciidae). Fisheries Research, 46(1): 5-13. doi: 10.1016/S0165-7836(00)00128-4

Tuset, V.M., Lozano, I.J., González, J.A., Pertusa, J.F. \& García-Díaz, M.M. (2003). Shape indices to identify regional differences in otolith morphology of scomber. Serranus cabrilla (L. 1758). Journal of Applied Ichthyology, 19(2): 88-93. doi: 10.1046/j.1439-0426.2003.00344.x

Tuset, V.M., Lombarte, A. \& Assis, C.A. (2008). Otolith atlas for the western Mediterranean north and central eastern Atlantic. Scientia Marina, 72(S1): 7-198. doi: 10.3989/scimar.2008.72s17

Vignon, M. \& Morat, F. (2010). Environmental and genetic determinant of otolith shape revealed by a non-indigenous tropical fish. Marine Ecology Progress Series, 411: 231-241. doi: 10.3354/meps08651

Viva, C., Sartor, P., Bertolini, D., De Ranieri. S. \& Ligas, A. (2015). Relationship of otolith length to fish total length in six demersal species from the NW Mediterranean Sea. Journal of Applied Ichthyology, 31(5): 973-974. doi: 10.1111/jai.12838

Waessle, J.A., Lasta, C.A. \& Favero, M. (2003). Otolith morphology and body size relationships for juvenile Sciaenidae in the Río de la Plataestuary (35$36^{\circ}$ S). Scientia Marina, 67(2): 233-240.

Yağcl, M.A., Alp, A., Yağcl, A. \& Uysal, R. (2014). Diet and Prey Selection of Pikeperch (Sander lucioperca Linnaeus, 1758) Population in Lake Eğirdir (Turkey). Archives of Biological Science Belgrade, 66(4): 1515-1527. doi: 10.2298/ABS1404515Y

Yılmaz, S., Yazıcıoğlu, O., Yazıcı, R. \& Polat, N. (2015). Relationships between fish length and otolith size for five cyprinid species from Lake Ladik, Samsun, Turkey. Turkish Journal of Zoology, 39(3): 438-446. doi: 10.3906/zoo-1403-58

Zan, X.X., Zhang, C., Xu, B.D. \& Zhang, C.L. (2015). Relationships between fish size and otolith measurements for 33 fish species caught by bottom trawl in Haizhou Bay, China. Journal of Applied Ichthyology, 31(3): 544548. doi: 10.1111/jai.12751 